\title{
Sistem Informasi Manajemen pada PT. Andalas Bioteknologi Saiyo Padang
}

\author{
Dahniel Dahlan $^{1}$, Ilham Tri Maulana ${ }^{2}$, Gusrino Yanto ${ }^{3}$, Joe Faisal ${ }^{4}$ \\ Program Studi Sistem Informasi, STMIK Indonesia Padang 1,2,3,4 \\ e-mail: dahniel@stmikindonesia.ac.id'1, ilhamtm@stmikindonesia.ac.id ${ }^{2}$, \\ gusrinoyanto@stmikindonesia.ac.id ${ }^{3}$,njoe984@gmail.com ${ }^{4}$ \\ diterima: 12 Juni 2019 \\ direvisi: 5 Agustus 2019 \\ dipublikasi: 1 September 2019
}

\begin{abstract}
Abstrak
PT. Andalas Bioteknologi Saiyo Padang merupakan perusahaan yang bergerak dalam meyediakan bahan-bahan dan alat kedokteran. Dalam menjalankan usaha jasanya, proses administrasi perusahaan belum menggunakan perangkat lunak khususnya berupa sistem informasi manajemen. Sebuah perusahaan tentunya mempunyai sebuah pelaporan pengolahan data perusahaan. Saat ini pengolahan data masih bersifat manual yang mengakibatkan tidak optimalnya kinerja dari PT. Andalas Bioteknologi Saiyo Padang. Dengan dibuatnya sistem informasi manajemen yang baru, akan dapat memberikan keluaran yang cepat dan tepat untuk proses pengambilan keputusan. Metode pengembangan sistem yang digunakan dalam penelitian ini adalah metode waterfall. Alat bantu yang digunakan untuk merancang sistem menggunakan Unified Modeling Language (UML). Sistem informasi manajemen dikembangkan dengan kerangka berbasis website, dengan menggunakan bahasa pemograman PHP (Hypertext Preprocessor) dan database MySQL sebagai database server. Hasil akhir dari penelitian ini adalah terciptanya suatu sistem informasi manajemen PT. Andalas Bioteknologi Saiyo Padang yang dapat membantu karyawan dalam mengelola data Perusahaan yang tersistem dengan baik.
\end{abstract}

Kata kunci: Administrasi; Manajemen; Sistem Informasi Manajemen; Waterfall

\begin{abstract}
PT. Andalas Biotechnology Saiyo Padang is a company engaged in providing medical materials and equipment. In carrying out its business services, the administration process of the company has not used software suspecifically in the form of management information systems. A company certainly has a company data processing report. At present the data processing is still manual, resulting in not optimal performance of PT. Andalas Saiyo Biotechnology Padang. With the creation of a new management information system, it will be able to provide fast and appropriate output for the decision making process. The system development method used in this research is the waterfall method. Tools used for system design uses Unified Modeling Language (UML). Management information systems are developed with a website-based framework, using the PHP programming language (Hypertext Preprocessor) and MySQL database as a database server. The final result of this research is the creation of a management information system of PT. Saiyo Padang Andalas Biotechnology that can help employees manage Company data that is well-systemized.
\end{abstract}

Keywords: Administratio; Management; Management Information Systems; Waterfall 


\section{Pendahuluan}

Perkembangan ilmu pengetahuan dan teknologi dewasa ini telah mendorong manusia pada kehidupan yang lebih baik. Teknologi komputer dan internet saat ini bukan lagi suatu hal yang mahal dan sulit dicari melainkan telah menjadi suatu kebutuhan dasar dalam pengolahan dan pertukaran informasi baik lokal maupun secara global. Penggunaan teknologi komputer dan internet tidak terbatas pada satu tujuan melainkan untuk berbagai tujuan yang dimanfaatkan untuk bisnis maupun untuk tujuan yang lain. Terlebih lagi adanya komputer dimana hal tersebut semakin meningkatkan efisiensi dan kualitas dalam bekerja, dengan adanya komputer manusia diberi kemudahan dalam menyelesaikan pekerjaaan di berbagai bidang, misalnya bidang manajemen perdagangan. Teknologi informasi saat ini telah mengalami perkembangan yang sangat pesat khususnya pada sistem informasi sehingga instansi atau perusahaan dapat memanfaatkannya untuk mempermudah dalam melakukan setiap pekerjaan yang ada [1].

Seiring berkembangnya kemajuan teknologi informasi dan komunikasi perdagangan, persaingan bisnis dalam dunia industri semakin ketat. Banyak perusahaan melakukan usaha dan strategi dalam mempertahankan bisnisnya. Kesuksesan perusahaan dalam mempertahankan bisnisnya tidak lepas dari peran perusahaan dalam mengelola manajemen perusahaan. Dalam era teknologi informasi yang berkembang sangat pesat, proses administrasi perusahaan dan pelayanan data serta informasi bagi konsumen dapat dilakukan cepat, mudah dan akurat. Penerapan sistem informasi dalam sebuah organisasi memiliki tiga sasaran utama. Pertama, memperbaiki efisiensi kerja dengan melakukan otomasi berbagai proses yang mengelola informasi. Kedua, meningkatkan keefektifan manajemen dengan memuaskan kebutuhan informasi guna pengambilan keputusan. Ketiga, memperbaiki daya saing atau meningkatkan keunggulan kompetitif organisasi [2].

PT. Andalas Bioteknologi Saiyo, merupakan perusahaan yang bergerak dalam menyediakan bahan-bahan dan alat yang terkait biologi molekuler, imunolgi, kultur sel, diagnostik kedokteran. Dalam proses pengolahan data, pembukuan dan pengontrolan stok barang PT. Andalas Bioteknologi Saiyo pada masih bersifat manual dan saat terjadinya proses pemesanan barang yang tidak konsisten. Data merupakan bagian yang sangat penting di dalam suatu perusahaan. Proses pengelolaan data pada perusahaan ini belum terkomputerisasi secara maksimal, dimana semua file pekerjaan disimpan dalam folderfolder yang dibuat sendiri oleh staf perusahaan dalam format excel (*xls) dan word (*doc), dan belum menunjukan kepada Database Management System (DBMS). Hal ini akan menghambat ketika akan membuat laporan persedian barang dan jika ingin mengcek stok barang yang tersedia akan membutuhkan waktu yang cukup lama. Sedangkan karyawan kesulitan dalam membuat laporan penjualan, karena nota penjualan yang sering hilang sehingga pembuatan laporan tidak disajikan dengan optimal.

Dengan kondisi seperti ini, staf administrasi harus membuat surat-surat, rekapitulasi data, dan member informasi tentang perusahaan secara manual. Ini dirasakan tidak efisien dalam menjalankan bisnis perusahaan karena diperlukan waktu yang lama dalam pengerjaannya. Oleh karena itu, maka data seharusnya diolah sebaik mungkin sehingga dapat digunakan oleh pihak-pihak yang membutuhkan. Proses pelayanan jasa dengan penyampaian informasi terkait perusahaan, masih dilakukan secara konvensional yaitu perusahaan menyediakan staff di bagian pelayanan konsumen front-liner, yang bertugas memberikan informasi kepada konsumen baik melalui telepon maupun konsumen yang secara langsung mengunjungi perusahaan. Selain dengan front-liner, media informasi lainnya yang digunakan yaitu dengan membuat buku profil perusahaan dan brosur pelayanan jasa, dimana informasi ini hanya akan didapat jika konsumen berkunjung ke kantor. 
Dari beberapa permasalahan diatas dan untuk mengurangi kesalahan, meningkatkan kualitas layanan manajemen, meningkatkan kinerja dan memudahkan karyawan untuk mengolah data dari PT. Andalas Bioteknologi Saiyo diperlukan suatu sistem informasi manajemen yang terkomputerisasi yang dapat mendukung pengolahan data penjualan, persedian stok barang, data pembelian, laporan pembelian dan laporan penjualan secara tepat dan cepat sehingga memudahkan untuk mengambil keputusan yang dapat meningkatkan laba perusahaan dengan baik.

Tujuan penelitian ini adalah untuk mengembangkan sistem informasi manajemen yang dapat mendukung dalam proses penjualan, pembelian barang dan memudahkan proses input data barang serta pengecekan stok barang. Tujuan berikutnya adalah untuk membantu PT. Andalas Bioteknologi Saiyo dalam pembuatan laporan seperti laporan penjualan, pembelian barang dan laporan persediaan barang dengan cepat sehingga dihasilkan informasi yang akurat untuk memudahkan dalam pengambilan keputusan juga untuk membantu PT. Andalas Bioteknologi Saiyo agar tidak melakukan sebagian kegiatan secara manual tetapi telah terkomputerisasi dan kelancaran aktifitas pada PT. Andalas Bioteknologi Saiyo.

\subsection{Sistem Informasi}

\section{Kajian Pustaka}

Sistem Informasi adalah suatu sistem di dalam suatu organisasi yang mempertemukan kebutuhan pengolahan transaksi harian yang mendukung fungsi operasi organisasi yang bersifat manajerial dengan kegiatan strategi dari suatu organisasi untuk dapat menyediakan kepada pihak luar tertentu dengan laporan - laporan yang diperlukan [3].

Sistem Informasi adalah kombinasi dari orang-orang, perangkat keras, perangkat lunak, jaringan komunikasi, sumber daya data, dan kebijakan serta prosedur dalam menyimpan, mendapatkan kembali, mengubah, dan menyebarkan informasi dalam suatu organisasi [3]. Sistem Informasi merupakan sistem yang mempunyai kemampuan untuk mengumpulkan informasi dari semua sumber dan menggunakan berbagai media untuk menampilkan informasi [4].

Dari pendapat ahli diatas dapat disimpulkan bahwa sistem informasi adalah kumpulan komponen dan elemen menggunakan teknologi komputer untuk mengumpulkan, memproses, menyimpan, menganalisis dan menyebarkan informasi yang diperlukan oleh pihak tertentu dalam pengambilan keputusan.

\subsection{Sistem Informasi Manajemen}

Sistem informasi manajemen adalah sistem terpadu yang menyediakan informasi untuk mendukung kegiatan operasional,manajemen, dan fungsi pengambilan keputusan dari suatu organisasi [5]. Sistem informasi manajemen sebagai sistem informasi yang menghasilkan hasil keluaran (output) dengan menggunakan masukan (input) dan berbagai proses yang diperlukan untuk memenuhi tujuan tertentu dalam suatu kegiatan manajemen [6]. sistem informasi manajemen adalah sebuah metode formal untuk menyediakan informasi yang akurat dan tepat waktu bagi manajemen yang diperlukan untuk mempermudah proses pengambilan keputusan, dan memungkinkan fungsi-fungsi dari manajemen seperti perencanaan, pengendalian, dan operasional organisasi dapat dilaksanakan secara efektif [7].

Berdasarkan pendapat diatas, Sietm informasi manajemen dapat dikatan sebagai sebuah sistem manusia dan mesin yang terintegrasi dalam menyediakan informasi guna mendukung fungdi operasi manajenen dan penentuan alternatif tindakan dalam sebuah organisasi sistem tersebut. 


\subsection{Pengertian Persediaan Barang}

Persediaan adalah barang yang dimiliki oleh perusahaan untuk dijual kembali atau diproses kembali. Persediaan merupakan aset dan merupakan unsur aktifa lancar dalam neraca. Persediaan merupakan bahan-bahan dalam proses yang terdapat dalam perusahaan untuk proses produksi, serta barang-barang jadi atau produk yang disediakan untuk memenuhi permintaan dari konsumen atau pelanggan setiap waktu [8]. Dari pengertian di atas dapat disimpulkan bahwa pengertian persediaan barang adalah barang-barang yang disimpan dan disediakan untuk memenuhi permintaan dari konsumen setiap waktu atau dijual pada masa yang akan datang.

\subsection{Pembelian}

Prosedur pembelian adalah urutan-urutan dari kegiatan pembelian yang dilaksanakan melalui beberapa bagian dalam perusahaan, bagian yang terkait dalam prosedur ini adalah bagian pembelian, penerimaan barang, hutang dan dagang. Proses pembelian adalah struktur interaksi antara orang-orang, peralatan, metode-metode, dan pengendalian yang didesain untuk mencapai fungsi-fungsi utama sebagai berikut: Menangani rutinitas pekerjaan yang berulang-ulang dari departemen pembelian dan departemen penerimaan, mendukung kebutuhan pengambilan keputusan dari orang-orang yang mengatur departemen pembelian dan departemen penerimaan dan membantu dalam penyiapan laporan internal dan laporan eksternal. Fungsi pembelian barang sebenarnya berada dibawah atap fungsi logistik. yang dimaksud dengan fungsi logistik adalah fungsi perencanaan dan pengendalian aliran fisik barang yang mengalir ke segenap bagian organisasi [9].

\subsection{Penjualan}

Penjualan merupakan kegiatan yang dilakukan oleh penjual dalam menjual barang atau jasa dengan harapan akan memperoleh laba dari adanya transaksitransaksi tersebut dan penjualan dapat diartikan sebagai pengalihan atau pemindahan hak kepemilikan atas barang atau jasa dari pihak penjual ke pembeli. Penjualan adalah pendapatan lazim dalam perusahaan dan merupakan jumlah kotor yang dibebankan kepada pelanggan atas barang dan jasa [4]. Dapat disimpulkan penjualan adalah pemindahan hak kepemilikan atas barang atau jasa yang yang dilakukan perusahaan sebagai usaha pokok.

\section{Metode Penelitian}

Metode penelitian yang digunakan yaitu SDLC (System Development Life Cycle) tipe waterfall. SDLC suatu metode atau tahapan yang harus dikerjakan oleh pengembang suatu perangkat lunak untuk menghasilkan suatu perangkat yang dapat digunakan oleh pemakai atau user [10]. Model Waterfall ini sebenarnya adalah "Linear Model", yang sering disebut juga dengan "classic life cycle", Model waterfall menyediakan pendekatan alur hidup perangkat lunak secara sekuensial atau terurut dimulai dari analisis dan definisi kebutuhan, Perancangan sistem dan perangkat lunak, Impelementasi dan pengujian unit, Integrasi dan pengijian sistem, dan Operasi dan pemeliharaan seperti yang di tunjukan pada Gambar 1 [3].

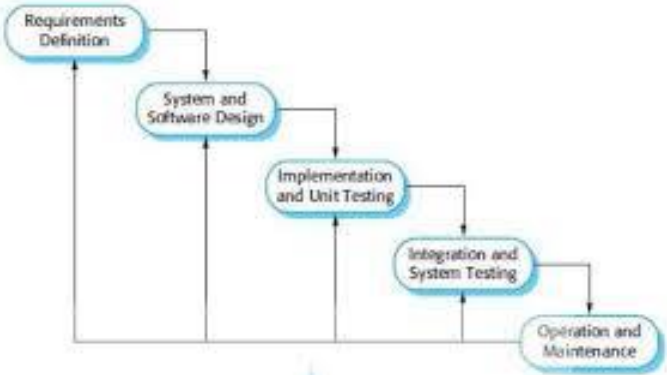

Gambar 1. Metode Waterfall 
Adapun penjelasan dari Gambar 1 diatas adalah:

1) Analisis dan definisi kebutuhan. Layanan, batasan dan tujuan sistem ditentukan melalui konsultasi dengan user atau pemakai.

2) Perancangan sistem dan perangkat lunak. Proses perancangan sietem membagai persyaatan dalam sistem perangkat kearas atau perangkat lunak. Kegiatan ini mementukan arsiktektur sistem secara keseluruhan.

3) Impelementasi dan pengujian unit. Pada tahap ini, perancangan perangkat lunak direalisasikan dengan program atau unit program.

4) Integrasi dan pengijian sistem. Unit program atau program individual diintegrasikan dan diuji sebagai sistem yang lengkap untuk menjamin bahwa kebutuhan sistem telah dipenuhi.

5) Operasi dan pemeliharaan, yaitu mengoprasikan program dalam lingkunganya dan melakukan pemeiliharaan. Biasanya ini merupakan fase siklus hidup yang paling lama.

\subsection{Hasil}

\section{Hasil dan Pembahasan}

\subsubsection{Use Case Diagram}

a. Use Case Diagram untuk halaman admin dapat dilihat seperti Gambar 2.

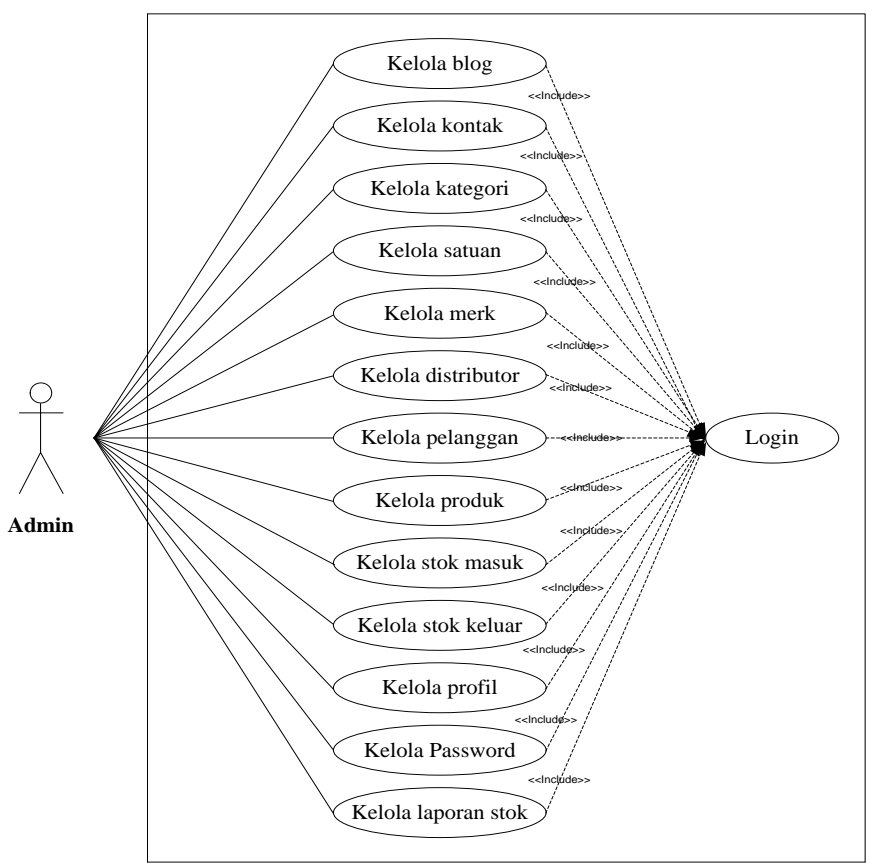

Gambar 2. Use Case Diagram Admin

Pada Gambar Use Case Diagram halaman admin diatas menggambarkan pilihan halaman menu yang dapat dikelola oleh pegawai/admin, yaitu: kelola blog, kelola kategori, kelola satuan, kelola merk, kelola distributor, kelola pelanggan, kelola produk, kelola stok masuk, kelola stok keluar, kelola kelola profil, kelola password dan kelola laporan stok barang.

b. Use Case Diagram Pelanggan

Use Case Diagram untuk halaman pelanggan dapat dilihat seperti Gambar 3. 


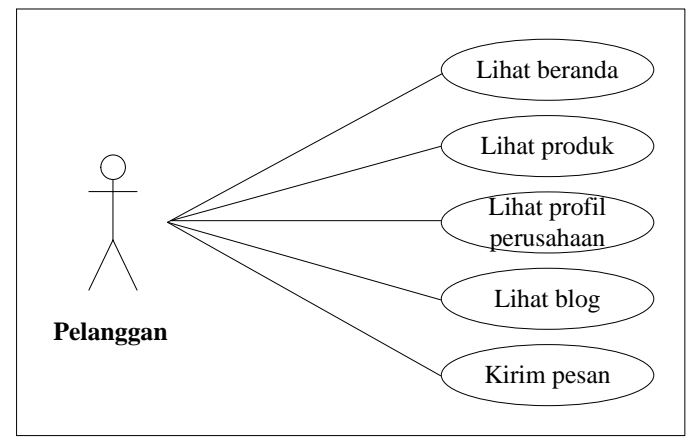

Gambar 3. Use Case Diagram Pelanggan

Pada Gambar 3, Use Case Diagram halaman pelanggan diatas menggambarkan pilihan halaman menu yang dapat dilakukan oleh pelanggan yaitu : lihat beranda, lihat produk, lihar profil perusahaan, lihat blok dan kirim pesan ke admin.

\subsubsection{Sequence Diagram}

a. Sequence Diagram adalah diagram yang menggambarkan kelakukan objek pada Use Case dengan mendeskripsikan waktu hidup objek dan pesan yang dikrim dan diterima antar objek.

1) Sequence Diagram admin dapat dilihat pada Gambar 4.

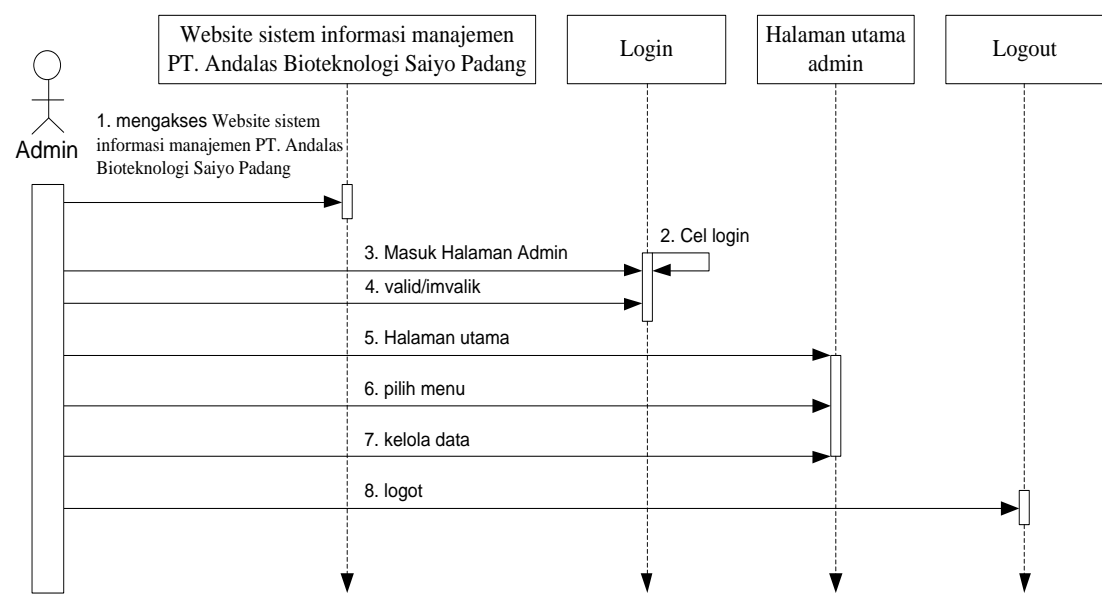

Gambar 4. Sequence Diagram Admin

Adapun penjelasan dari Gambar 4 diatas adalah:

a) Admin mengakses website Sistem Informasi Manajemen PT. Andalas Bioteknologi Saiyo Padang dan melakukan login.

b) Admin masuk ke halaman utama pada halaman admin setelah berhasil melakukan login.

c) Admin memilih menu pada halaman admin Admin mengelola data sarana dan pemeriksaan dan melakukan logout.

2) Sequence Diagram Pelanggan

Untuk sequence diagram pelanggan dapat dilihat pada Gambar 5. 


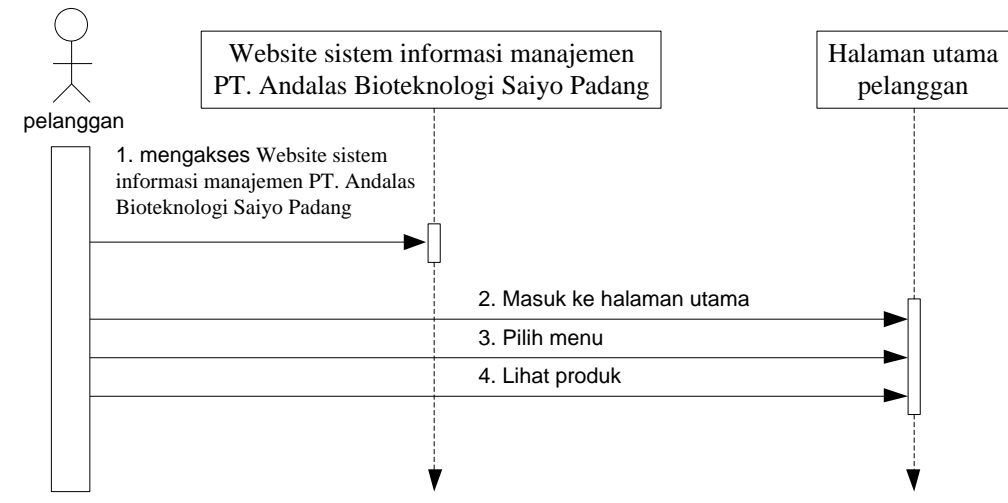

Gambar 5. Sequence Diagram Pelanggan

Adapun penjelasan dari Gambar 5 diatas adalah:

a) Pelanggan mengakses website Sistem Informasi Manajemen PT. Andalas Bioteknologi Saiyo Padang.

b) Admin masuk ke halaman utama.

c) Admin memilih menu pada halaman admin menu pelanggan dan melihat produk.

\subsubsection{Class Diagram}

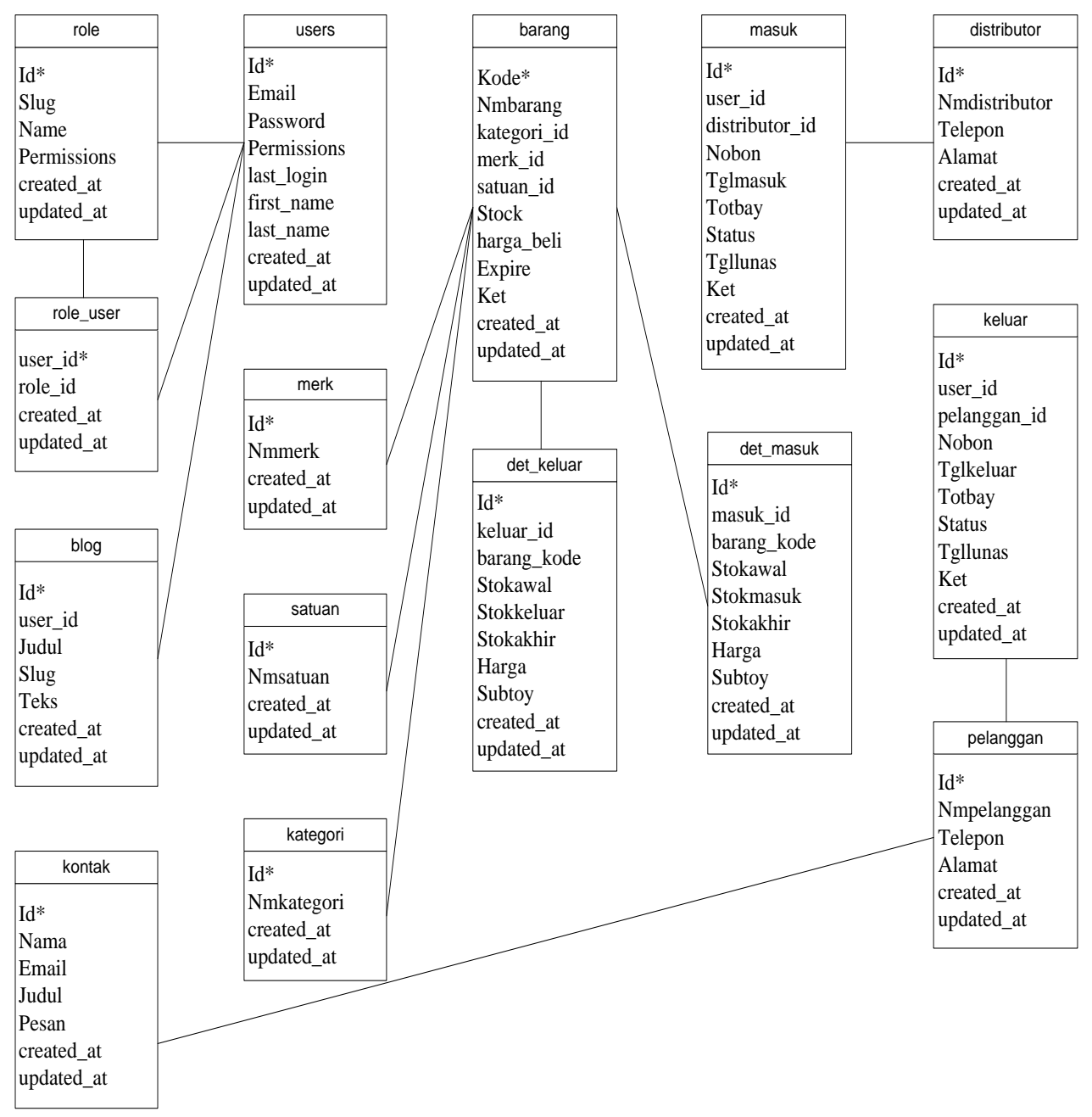

Gambar 6. Class Diagram 
Class Diagram pada Gambar 6 diatas mendefenisikan informasi apa yang dimiliki suatu objek serta mendefinisikan perilaku yang dimilikinya. Class mengabstraksikan elemen-elemen dari sistem yang sedang dibangun dan dirancang.

\subsubsection{Implementasi Antar Muka Halaman Menu}

Antar muka halaman utama yang dapat dilihat pada Gambar 7.

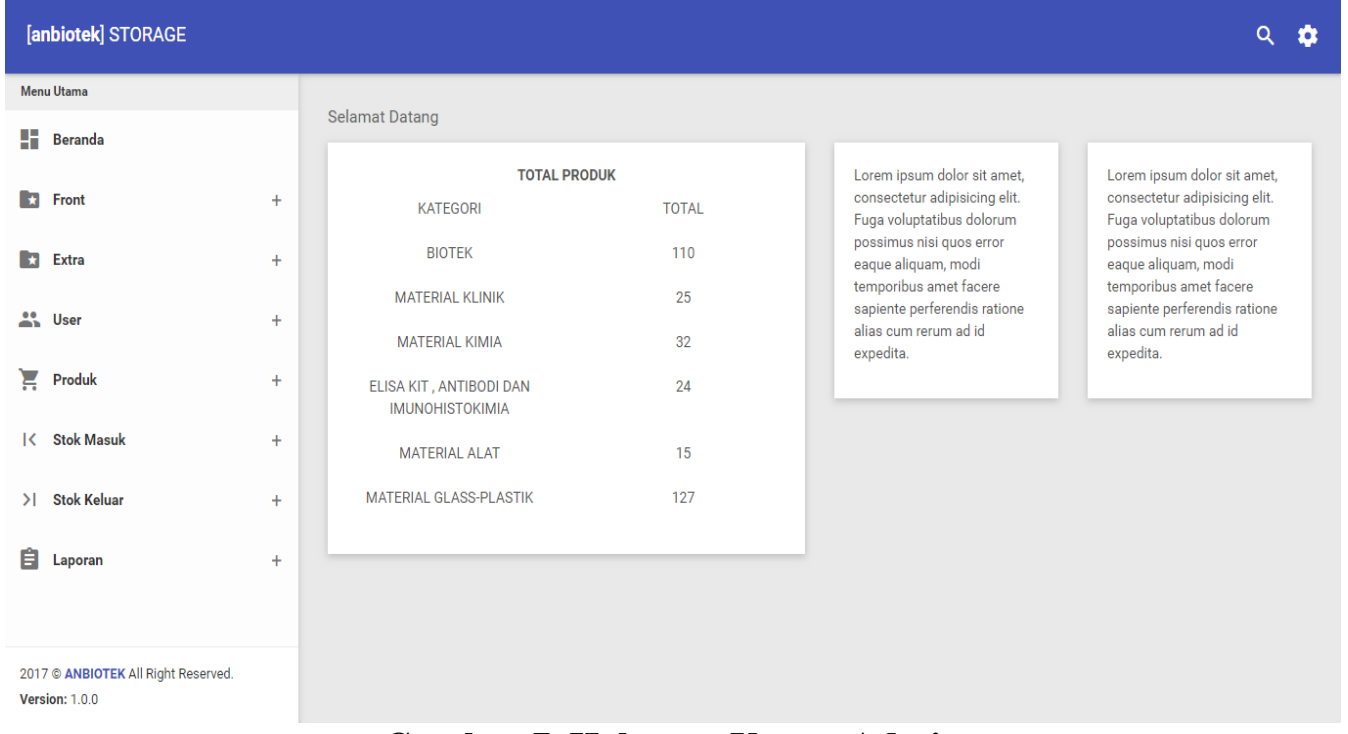

\section{Gambar 7. Halaman Utama Admin}

Menciptakan kerangka dasar dari beberapa sub program yang ada didalamnya sebagai tampilan utama dari program sistem informasi manajemen pada PT. Andalas Bioteknologi Saiyo. Pada bagian halaman utama terdapat beberapa menu untuk menampilkan keseluruhan sub-sub menu tersebut dieksekusi dalam menu utama

\subsubsection{Implementasi Antar Muka Form Input}

Antar muka Form Input yang dapat dilihat pada Gambar 8.

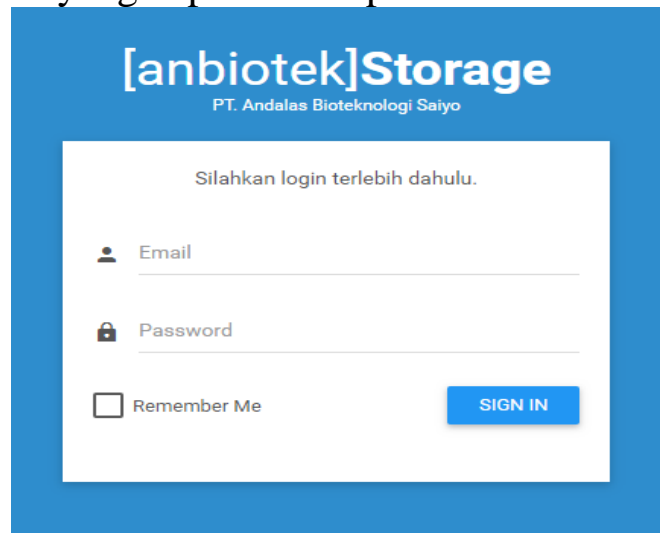

Gambar 8. Form Input Login

Program yang dirancang merupakan suatu program yang saling berkaitan antara satu menu dengan menu yang lainnya maka user harus melakukan tahap demi tahap atau langkahlangkah yang sudah dirangcang. Maka tahap pertama yang harus dilakukan oleh user adalah menginput data, berikut ini akan dijelaskan bentuk dari input data tersebut secara lebih rinci. Form Login Admin dapat mengakses halaman admin atau petugas dengan login terlebih dahulu pada form login yang dapat dilihat pada Gambar 8 diatas. 


\subsubsection{Pembahasan dan Pengujian Sistem}

Tahap terakhir dalam pengembangan Sistem Informasi Manajemen Pada PT. Andalas Bioteknologi Saiyo Padang adalah pengujian. Pengujian dilakukan oleh peneliti menggunakan metode Blackbox, pengujian oleh ahli serta pengujian oleh pengguna sistem. Pada penelitian ini masih pada tahap pengujian Blackbox. Pengujian dengan metode Blackbox adalah pengujian yang dilakukan untuk mengetahui fungsionalitas dari sebuah sistem informasi. Metode ini menguji berbagai fungsi yang terdapat pada sistem informasi yang dikembangkan. Berdasarkan pengujian yang dilakukan peneliti, menghasilkan bahwa semua fungsi dalam Sistem Informasi Pengolah Nilai sudah berjalan dengan baik dan sistem informasi ini siap diujikan kepada ahli dan juga pengguna. Pengujian yang dilakukan antara lain pengujian pendaftaran distributor, pendaftaran pelanggan, penambahan data produk, penambahan stok masuk dan stok keluar oleh admin. Hasil pengujian dilampirkan sebagai berikut.

1. Pengaturan atau konfigurasi Tes dan level tes ditunjukkan pada Gambar 9.
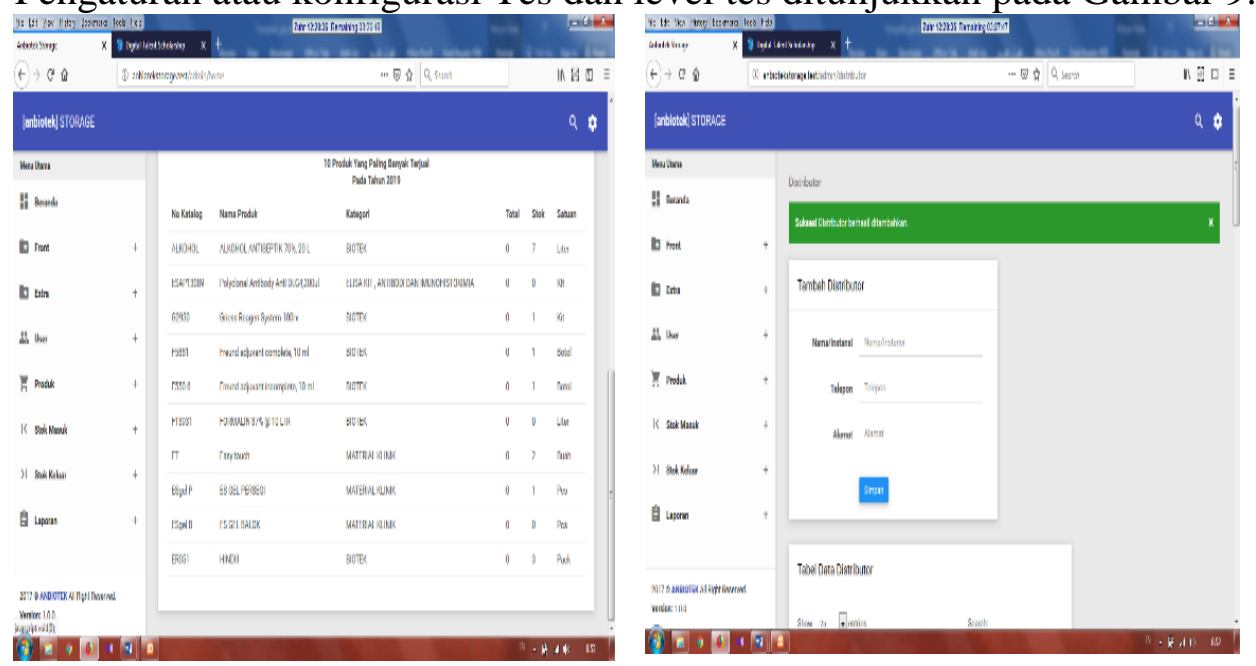

\section{Gambar 9. Pengaturan Tes}

2. Pengaturan stok masuk dan stok keluar ditunjukkan pada Gambar 10.
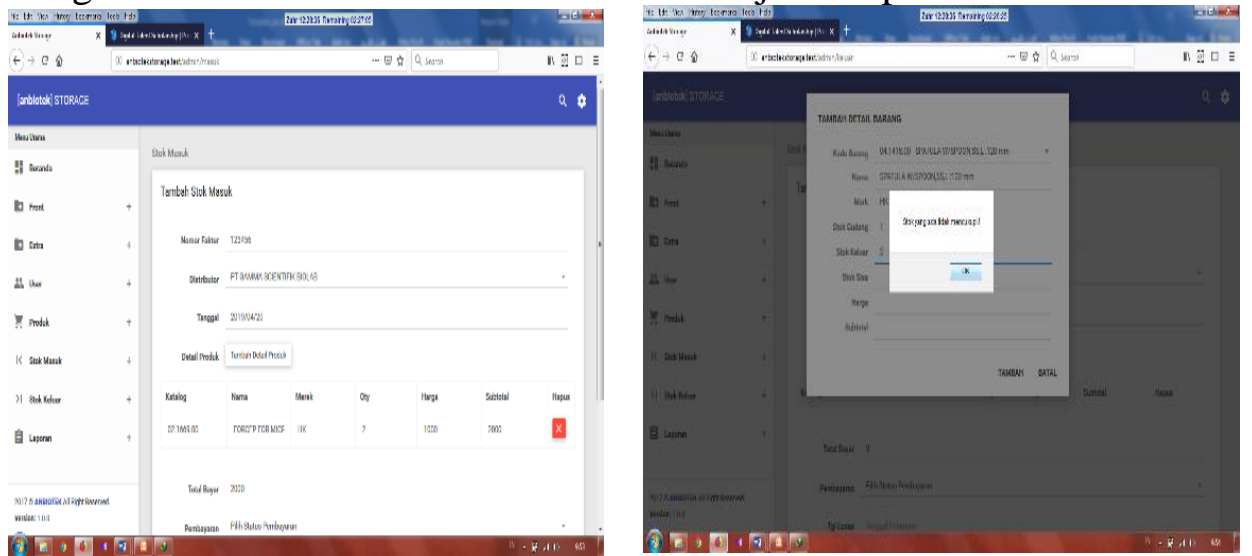

Gambar10. Penambahan materi dan Kompetensi materi

\section{Kesimpulan}

Berdasarkan penjelasan dan uraian mengenai sistem informasi manajemen pada PT. Andalas Bioteknologi Saiyo Padang serta analisis dari data yang ada, maka dapat diambil beberapa kesimpulan, yaitu dengan adanya sistem informasi manajemen ini penyajian data dilaksanakan secara terkomputerisasi yaitu data pembelian, data penjualan, persedian stok 
barang, laporan penjualan dan laporan pembelian, Sistem informasi manajemen ini dapat membantu mengontrol stok barang secara cepat, tepat dan akurat, Pemesanan yang lebih konsisten karena sudah terkomputerisasi sehingga tidak menghambat dalam penyajian laporan dan sistem yang baru sudah menggunakan database sehingga tidak terjadi kehilangan data sehingga dapat menyajikan laporan secara optimal. Dalam penelitian ini ditemukan kekurangan-kekurangan dalam pemenuhan kebutuhan informasi. Untuk itu kiranya diperlukan saran-saran yang diharapkan dapat membantu diantaranya, yaitu: Sebelum sistem diterapkan, sebaiknya dilakukan pelatihan-pelatihan terhadap karyawan yang terlibat dalam pemakaian sistem ini sehingga memudahkan mereka dalam menggunakan sistem ini. Yakinkan semua karyawan yang terlibat dalam pemakaian sistem ini, bahwa kehadiran sistem baru ini hanyalah sebagai alat bantu untuk memudahkan pekerjaan yang dihadapi agar informasi yang di inginkan tidak mengalami keterlambatan. Jika sistem ini ingin dikembangkan, tambah fitur dengan menggunakan barcode sehingga memudahkan admin / pegawai dalam menginput barang masuk.

\section{Ucapan Terima Kasih}

Ucapan terima kasih kita ucapkan kepada STMIK Indonesia Padang yang memberikan support untuk penelitian ini.

\section{Daftar Pustaka}

[1] A. Rusmi, Rusdisal, Tri Aprianto Sundara, "Sistem Informasi Pelaporan Kerusakan Sarana Dan Prasarana pada Asrama Mahasiswa Universitas Andalas Padang," Indones. J. Comput. Sci., vol. 8, no. 1, pp. 78-90, 2019.

[2] F. Hakam, E. Nugroho, and A. Meliala, "Analisis Sistem Dan Teknologi Informasi Sebagai Acauan Dalam Perancangan Rencana Strategis Sistem Informasi Dan Teknologi Informasi (RENSTRA SI/TI) Di Rumah Sakit Islam Yogyakarta PDHI," J. Sist. Inf., vol. 9, no. 1, pp. 1197-1203, 2017.

[3] I. T. Maulana, "Sistem Informasi Perpustakaan Online di Man Kota Solok," J. Inform. Upgris, vol. 4, no. 2, pp. 127-134, 2018.

[4] S. A. Wulandari, "SISTEM INFORMASI PENJUALAN PRODUK BERBASIS WEB PADA CHANEL DISTRO PRINGSEWU," J. TAM (Technology Accept. Model., vol. 4, pp. 41-47, 2015.

[5] I. D. Utami, I. Santosa, R. Annisa, I. R. Simanjuntak, and U. A. Permatasari, "Sistem Informasi Manajemen Berbasis Web pada Usaha Mikro Kecil Dan Menengah ( UMKM ) ( Studi Kasus : UMKM Sumber Jokotole, Socah, Bangkalan )," J. Inf. Technol., vol. 4, no. 1, pp. 1-10, 2019.

[6] H. M. Susanto, W. Mantja, I. Bafadal, and A. Sonhadji, "Pengembangan Sistem Informasi Manajemen Pendidik dan Tenaga Kependidikan," J. Pendidik. Hum., vol. 3, no. 2, pp. 93-105, 2015.

[7] R. S. La Ode Ismail Ahmad, "PENERAPAN SISTEM INFORMASI MANAJEMEN PENDIDIKAN DALAM PROSES PEMBELAJARAN DI SMP NEGERI 21 MAKASSAR,” J. Idaarah, vol. I, no. 2, pp. 290-309, 2017.

[8] Freddy Rangkuti, Manajemen Persediaan Aplikasi di Bidang Bisnis. PT.Raja Grafindo Persada, 2004.

[9] A. Febriani Yusnensi, Fitro Nur Hakim, Solechan, "PENGEMBANGAN SISTEM INFORMASI PENJUALAN, PEMBELIAN DAN PERSEDIAAN BERBASIS 
WEB)," J. Sist. Inf. DAN TENOLOGI, vol. 1, pp. 155-160, 2018.

[10] F. F. Ilham Tri Maulana, "Perancangan Media Pembelajaran Multimedia Interaktif Untuk Mata Kuliah Aplikasi Software," J. SAINS DAN Inform., vol. 3, no. 12, pp. 8996, 2017. 